\title{
A scientific note of pest-insects associated with stingless bee hive Melipona eburnea in the Ecuadorian Amazon Region
}

\author{
Una nota científica de insectos-plaga asociados con las colmenas de abejas sin aguijón \\ Melipona eburnea en la región amazónica ecuatoriana
}

Fernando Valdivieso-Rivera ${ }^{1 *}$, Michelle Pazmiño-Viteri ${ }^{1}$, Alejandro Pinos-Tamayo ${ }^{1}$, Marlon Estupiñan², Jonathan Liria ${ }^{1}$, Cecilia Rodriguez-Haro ${ }^{1}$

DOI. 10.21931/RB/2021.06.04.33

Resumen: Bees are the primary pollinators in nature. However, climate change, excessive use of fertilizers and invasive species have caused the decline of bee colonies. Therefore, this study aimed to analyze the presence of pests in colonies of Melipona eburnea. For this, the colonies of $M$. eburnea were examined during the honey extraction process. We found 4 different pests associated with the physical conditions of colonies and the fragile defense of the bees against the invaders. In conclusion, this report of the presence of pests is to alert researchers and meliponicultures to prevent the decline of stingless bees.

Palabras clave: Honey production, meliponiculture, propolis, stingless bees.

Abstract: Las abejas son los principales polinizadores en la naturaleza. Sin embargo, la influencia del cambio climático, el uso excesivo de fertilizantes y especies invasoras han provocado la disminución de sus colonias. El objetivo del presente estudio fue analizar la presencia de plagas en colonias de Melipona eburnea. Se examinaron las colonias de M. eburnea durante el proceso de extracción de miel. Cuatro plagas diferentes fueron encontradas, asociadas con las condiciones físicas de las colonias y la frágil defensa de las abejas contra los invasores. En conclusión, este informe de plagas es para alertar a los investigadores y meliponicultores y evitar el declive de las abejas sin aguijón.

Key words: Abejas sin aguijón, meliponicultura, producción de miel, propóleos.

\section{Introduction}

Bees are a group of efficient pollinating insects since they visit the flowers constantly; appreciating this food habit, they have come to offer a significant ecological and economic importance ${ }^{1}$. In this context, the interaction between plant-pollinator ensures the survival and reproduction of plants². However, interactions that depend highly on a specific type of pollinator, there will be a high vulnerability of rupture and subsequent collapse when it is absent. An example of pollinators are bees of the Meliponini tribe that are widely distributed in the Neotropics and one of Melipona genus; it has been reported 16 species in Central America and 60 in South America ${ }^{3}$. In Ecuador, Colombia, Venezuela, and Brazil, some species of this genus have been documented ${ }^{4}$.

In Ecuador, the use of these bees for the production of honey is not widespread, and it has been recorded that in the provinces of Zamora, Morona Santiago and Loja are dedicated to meliponiculture with six species; Melipona eburnea (Friese, 1900); M. cf. indecisa, M. mimetica (Cockerell, 1919); M. rufiventris (Lepeletier, 1836) and two unidentified species ${ }^{5}$. Unfortunately, cases have been reported in which the colonies disappear, but in most of these, the reason is unknown ${ }^{5}$.

One of the reasons for the decline in bees is viruses that are transmitted by mites ${ }^{6-9}$. There are few studies on parasites (virus vectors) and pests that can affect stingless bees compared to $A$. mellifera ${ }^{10}$, even though the oldest bee fossil that has been found corresponds to a stingless one ${ }^{2,11}$. In this study, we analyzed the presence of pests and parasites in M. eburnea from meliponaries in Porotoyacu community of the Ecuadorian Amazon Region.
M. eburnea was recollected manually of 11 boxes in the Porotoyacu community (052'31.25" S and77 44'54.37" 0, 811 masl), Napo province, Ecuador. The community is responsible for extracting honey in an artisanal way, so the hives are built by hand. These are placed in wooden boxes on top of their roofs so that the bees can take advantage of the grape plantations near their homes. We collected workers of stingless bees, pollen and propolis, which were placed in plastic jars and airtight covers Ziploc ${ }^{\circledR}$, respectively. These were taken to the laboratory and stored in a $96 \%$ alcohol solution. The Motic ${ }^{\circledR}$ optical microscope model BA210 and a Motic ${ }^{\circledR}$ stereoscope model SMZ168 were used to analyze the samples. Keys corroborated the bee's taxonomic identification following ${ }^{12,13}$.

After analyzing and recognizing the organisms present in the samples taken, four pests of the stingless bee colony were identified. One of the specimens collected in the field was identified as part of the insect order Psocoptera (without wings; apterous) (Figure 1, A). All the species described to date (5000) are free-living and do not have parasitic characteristics ${ }^{14,15}$. According to several studies, Psocoptera feeds on microorganis$\mathrm{ms}$, mainly fungal organisms, which are agents in the process of organic matter degradation; in other words, the presence of these insects can be considered as an indicator of some decomposition process ${ }^{16}$. probably due to the disproportionate dimensions of the box that contained the colony of bees and the intervention of some abiotic factors, there was a process of decomposition of organic matter by fungi and other microorganisms, causing Psocoptera to enter into the hive. This decom- 
position could spread to the bee-hive, where the stability can be compromised, generating that these insects at this point might be considered to be pests. The microenvironments present in the Amazon forests, characterized by the density of forests, high temperatures, humidity, and shaded areas, are ideal for developing microorganisms that serve as a source of food for the Psocoptera. On the other hand, the principal depredators of Psocoptera are spiders, Coleoptera and/or Hemiptera ${ }^{14}$, we observed spiders around the box (bee-hive), so it can be interpreted that maybe Psocoptera was escaping from them.

The colony of M. eburnea was also infested with adult hoverflies (Diptera, Syrphidae) (Figure 1, B), that were found in the propolis, and according to Moquet $L 2018^{17}$, these invertebrates depend on pollen (a substance rich in proteins consumed by females for reproduction) and nectar (a substance rich in sugars consumed by females and males for obtaining energy). In this context, we can suggest that the hoverflies were stealing the floral resources of the colony, and the stingless bees were defending themselves, killing them.

Another organism found in the colony was a Lepidoptera: Noctuidae (larva) (Figure 1, C), with almost 300 species around the world being considered as pests to crop in the majority of cases $^{18}$. However, there is no information about Lepidoptera found in the colony of stingless bees or honeybee of the Apis genus. Furthermore, Lepidoptera feed with herbaceous plants and in the colony, no remains of herbs that could serve as food were observed, so it is inferred that perhaps some Lepidoptera left eggs inside the colony due to the ample space in the hive bees.

Finally, an ant (Hymenoptera: Formicidae), an adult insect (Figure 1, D) was observed

in the hive of bees $M$. eburnea. The presence of these in- sects has been detailed in the literature,

such as Campanotus pennsylvanicus Degeer ${ }^{19}$ and Solenopsis invicta Buren ${ }^{20,22}$. It has been described that these can be considered as a pest because they can exterminate whole colonies of bees. Experts and beekeepers recommend the use of extra protection in places where ants can climb and stay. Also, it is helpful to use materials such as slaked lime, ash, and oil with water. It's important to remember not to use any chemicals because they are toxic to these insects ${ }^{22}$.

Herein we provide the first report of four possible pests of meliponaries in the Amazon Region Of Ecuador to alert meliponicultures and researchers to be vigilant to prevent the diffusion of these pests throughout Ecuador and Amazon Region.

\section{Conclusions}

Specimens of the orders Psocoptera, Diptera, Lepidoptera and Hymenoptera were founded, which according to several studies, can be considered as pests for the bee colony, mainly involved in processes of decomposition of organic matter and competition for resources. However, future work will investigate all impacts in lifestyle and /or diseases in bees due to these invasive species. Furthermore, we hope that our research will be helpful to motivate similar studies in Melipona bees that are used for the production and commercialization of honey in the Amazon region.

\section{Acknowledgments}

The authors would like to thank the community Porotoyacu-Ecuador for their help during the study and Universidad Regional Amazónica Ikiam for financial support.

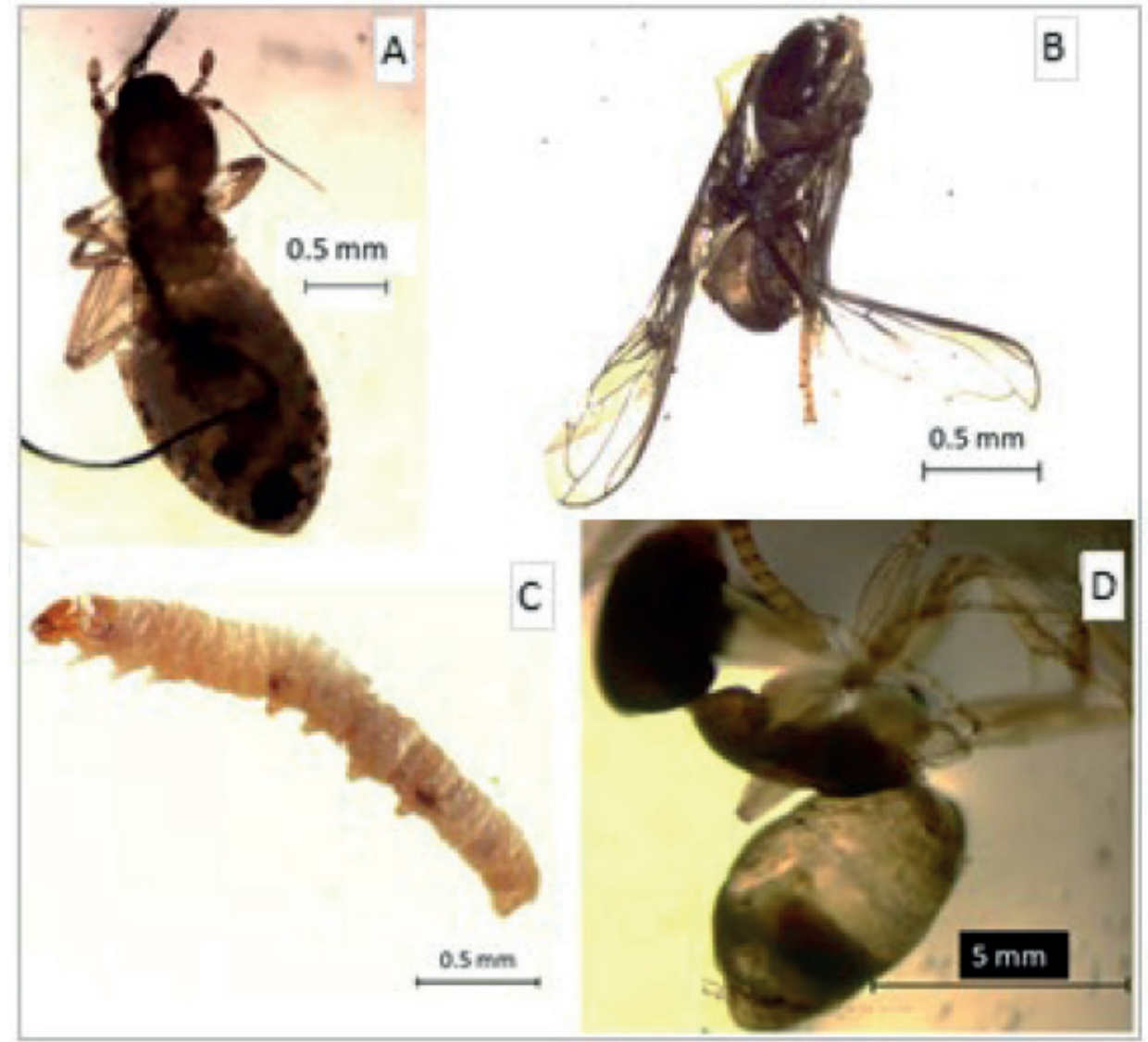

Figure 1. Pests in the colonies of Melipona eburnea. A: Psocoptera, B: Diptera, Syrphidae, C: Lepidoptera, Noctuidae (larvae), D: Hymenoptera, Formicidae, an adult. 


\section{Author Contribution Statement}

All authors conceived, designed research, conducted experiments, and wrote the manuscript. All authors read and approved the manuscript.

\section{Bibliographic references}

1. Nates-Parra G. Abejas silvestres y polinización. Manejo Integrado de Plagas y Agroecología. 2005;75:7-20. Available from: https:// biblat.unam.mx/ [Accessed 17 April 2019].

2. Nates-Parra G, Rodríguez C, Velez D. Stingless Bees (Hymenoptera: Apidae: Meliponini) in Oriental Mountains Cementeries from Colombia Acta Biológica Colombiana 2006;11:25-35.

3. Yurrita CL, Ortega-Huerta MA, Ayala R. Distributional analysis of Melipona stingless bees (Apidae: Meliponini) in Central America and Mexico: setting baseline information for their conservation. Apidologie. 2016;48(2):247-258. https://doi.org/10.1007/s13592016-0469-z.

4. Cortopassi-Laurino M, Imperatriz-Fonseca V, Roubik DW, et al. Global meliponiculture: challenges and opportunities Apidologie. 2006;37(2):275-292. https://doi.org/10.1051/apido:2006027.

5. Negrete I, Flores LG. Transparencia de nidos de Melipona Favosa Orbignyi Guerin, 1844 (Hymenoptera: Apidae: Meliponini) a cajas-colmenas y usos de su miel, desde el conocimiento del Pueblo Kichwa de la amazonía de Ecuador Boletín de la SEA. 2016;59:311-317. Available from: http://www.sea-socios.com/ Boletines/PDF/Boletin59/311317BSEA59Usosmieletnoentomologia.pdf [Accessed 17 August 2018].

6. Guzmán-Novoa E, Eccles L, Calvete Y. Varroa destructor is the main culprit for the death and reduced populations of overwintered honey bee (Apis mellifera) colonies in Ontario Apidologie. 2010;41(4):443-450. https://doi.org/10.1051/apido/2009076.

7. Nazzi F, Le Conte Y. Ecology of Varroa destructor, the major ectoparasite of the western honey bee, Apis mellifera Annu Rev Entomol. 2016;61:417-432. https://doi.org/10.1146/annurev-ento-010715-023731

8. Ryabov EV, Childers AK, Chen Y, et al. Recent spread of Varroa destructor virus-1, a honey bee pathogen, in the United States. Sci. Rep. 2017;7(1):17447. https://doi.org/10.1038/s41598-01717802-3

9. Shen M, Yang X, Cox-Foster D, et al. The role of varroa mites in infections of Kashmir bee virus (KBV) and deformed wing virus (DWV) in honey bees. Virology. 2005;342(1):141-149. https://doi. org/10.1016/j.virol.2005.07.012

10. Ueira-Vieira C, Oliveira-Almeida L, Corrêa De Almeida F, et al. Scientific note on the first molecular detection of the acute bee paralysis virus in Brazilian stingless bees Apidologie 2015;46:628630. https://doi.org/10.1007/s13592-015-0353-2

11. Vit P. Caracterización fisicoquímica de mieles de abejas sin aguijón (Meliponini) de Venezuela Revista del Instituto Nacional de Higiene Rafael Rangel. 2009;40(2):7-12.

12. Michener CD. The bees of the world. 2nd ed. Maryland, USA: The Johns Hopkins University Press; 2010.
13. Silveira F, Melo G, Almeida E. Abelhas brasileiras: sistemática e identificação. 1 ed. Brazil.: Biblioteca Nacional; 2002.

14. Mazáč D. The first contribution to the fauna of psocids (Insecta: Psocoptera) in forests in the Drahanská vrchovina Hills (Czech Republic). J. For. Sci. 2016;62(5):211-222. https://doi. org/10.17221/97/2015-jfs

15. Yoshizawa K, Johnson K. Phylogeny of the suborder Psocomorpha: congruence and incongruence between morphology and molecular data (Insecta: Psocodea: 'Psocoptera'). Zoo. J. Linn. So. 2014;171:716-731. https://doi.org/10.1111/zoj.12157

16. García-Aldrete AN. Biodiversidad de Psocoptera (Insecta: Psocodea) en México Revista mexicana de biodiversidad. 2014;85:252256. https://doi.org/10.7550/rmb.34417

17. Moquet L, Laurent E, Bacchetta R, et al. Conservation of hoverflies (Diptera, Syrphidae) requires complementary resources at the landscape and local scales. Insect Conserv. Div. 2018;11(1):72-87. https://doi.org/10.1111/icad.12245

18. San Blas G, Barrionuevo M. Status and redescription of the South American pest species Agrotis robusta (Lepidoptera: Noctuidae): a history of misidentifications. Revista Mexicana de Biodiversidad. 2013;84(4):1153-1158. https://doi.org/10.7550/rmb.36317

19. Oyerinde A, Ande A. Distribution and impact of honeybee pests on colony development in Kwara State, Nigeria. J. Agric. Soc. Sci. 2009;5(3):85-88

20. Weeks RD, Drees BM. Barrier treatments for red imported fire ants Solenopsi invicta in commercial honey bee operations. Southwestern Entomol. 2002;27(2):185-189.

21. Zhou A, Lu Y, Zeng L, et al. Solenopsis invicta (Hymenoptera: Formicidae), defend Phenacoccus solenopsis (Hemiptera: Pseudococcidae) against its natural enemies. Environ Entomol. 2013;42(2):247-252. https://doi.org/10.1603/EN12168.

22. Godoy F, Feversani S, APYM. Characteristics and breeding of the yateí and other meliponas J. Cedit. 2005;1:2-62.

Received: 5 Mayo 2021

Accepted: 1 Agosto 2021 